\title{
手術 手㧡
}

\section{鼻 欠損整形手術の経験}

\section{京都府立㘣科大学耳斯咽喉科学教室 (主任 中村交雄 教授)}

神谷識吉

京都第一日赤耳鼻咽隄科

松井隆 夫

緒简

顔面殊に鼻の缺損醜形は最る人目につき易く，時にはその人にとつて四肢の障碍以上に 精神的打 慗は大である。

最近鱟尖・両鼻翼・鼻橋を缺損した 1 例と鼻根部欠損の 1 例に遭遇し，何れも甚だしく顔面の醜 形を是していたが，皮膚淎移殖による整形を行い，未だ充分とはいえないが，一応移殖に成功した のでこっに報告する．

症例

(1) 鼻尖・莮翼・悬橋缺損 患者： 某 29 才 무

現病歴：眧和 23 年夏頃右鼻腔内

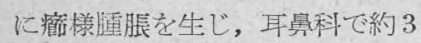
カ月その処置を受け，レ線照射を 行われたが軽快やず，其後瞥くし て舅头部に米粒大の発㢑を生じ, 以後皮膚科を転々とし，最後に尋 常性良䡒の衫断のるとに注射，光 線㿟法を約 1 力年続けた。

治態しないむ〉に，24年 5 月来 院皮宥科を訪れ，チビオン・太陽 登・レ線療法等により約 8 力月で 大本治忘の状態となつた。25年6月 産後約 3 力月で再発したが放置し， 装年 3 月再び本病院皮崕科で前述 の療法を約 1 カ年受けた。其の間病状は次第に增悪し, 舅尖部・両舅翼・中隔の一部圭缺損し，顔稆著しく䣨 形を星するに至つた (第1図)。27 年3月マイシン注 射，ヒドラジッド内服等により再び軽快に向い㹲痕治 療し現在に去つている(第2図。

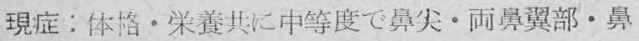

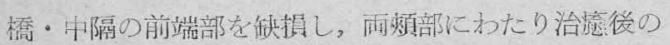

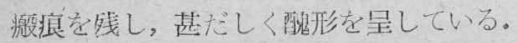

第 1 図

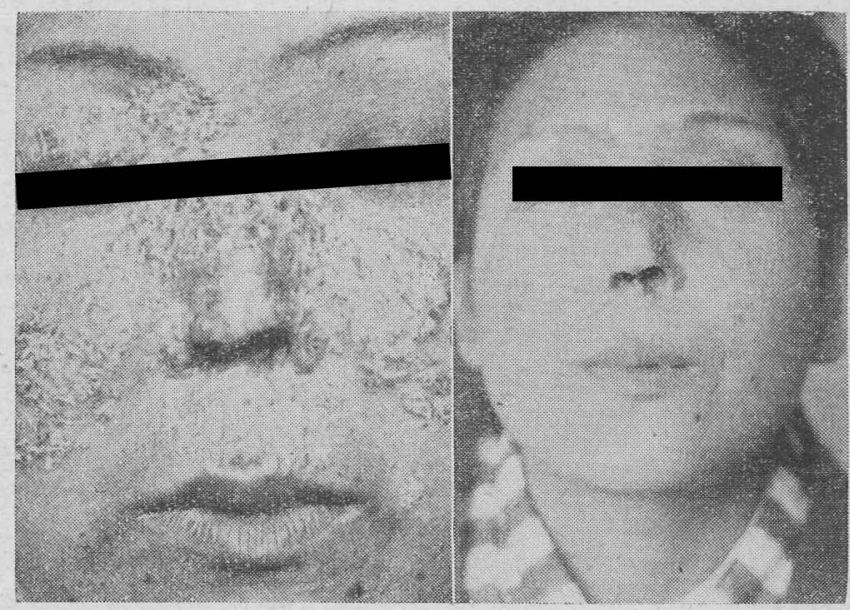

尋常性狼瘡に䍜思中
第 2 园 
第 3 図

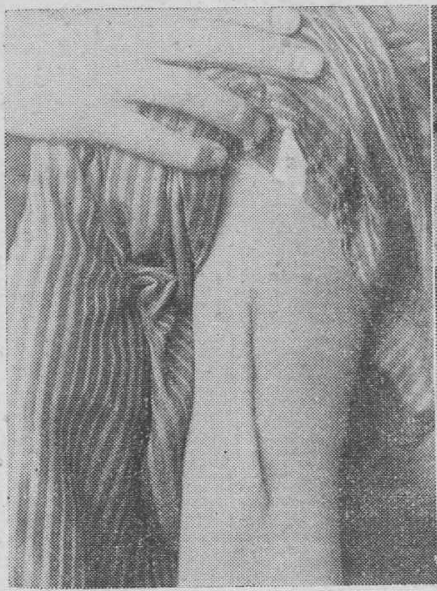

左上腕に浩つた发崖樁。

第 5 図

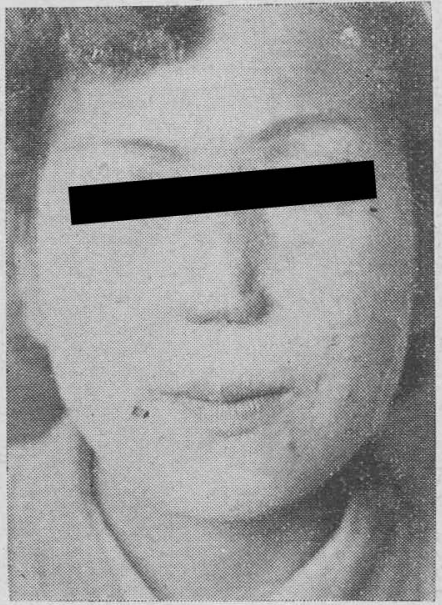

手術後鼻翼·鼻尖・並に舅橋を作る。

第 4 図

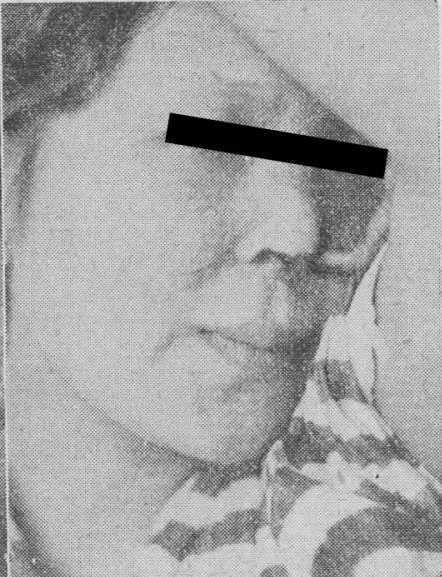

欠損部の左端へ縫合し，前腕 を頭上に固定.

その後一度度

掯捀の形を造り

な抏し, 約 3 力 月をへてその創 が治癔し美しく なるを待ち，28 年 3 月13日第二 回手術を実施し た(第 4 図)。

すなわら皮虞 捧上腕を離断 し, 上腕の創面 は直ちに縫合閉 鎖した。逝離端 を, 左舅望缺損 部皮䑶面以円形

に新しく作成した創面に鼾翼に相当するよう作成し， 左上肢は时関節で縌带固定し，約 2 週間後血液の循環 が充分であることを確めたのら第3 回手術を行つた (第5図)。まず鼻橋部形成のため，鼻橋缺椇部耐側 に前後に亘り幅 $0.7 \mathrm{~cm}$ 長さ $1.5 \mathrm{~cm}$ の四開を加え，勇橋根 部に残存した軟骨片を前端だけを残しやつ深めに可り

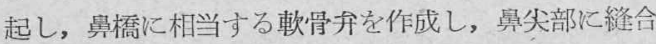
し，その後に合成樹脂板を入れて固定した。舅翼・具 尖缺損部には皮筍捧縫合のための創面を作り，文膚捧 は上腕基部より切り離し，両䔬翼・鼻尖に新しく作つ た創面に相当する幅約 $0.5 \mathrm{~cm}$ の浶状の創面を作り，
また中央部に幅約 $0.7 \mathrm{~cm}$ の畕橋に 相当

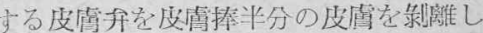
C作成し，舅底部よりの軟骨分に移殖し

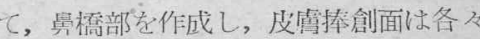

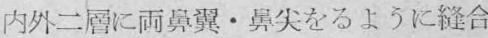

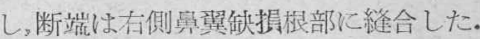
この回の手術は非常に複雑であつたた わ，創面は一時㣪環障的のため存半部が

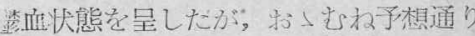
に移植し得た。

然し術後の所見は，出甯捧を移植した ものであるためその形は初め予想した程 には美しくはならなからた。

(2) 舅根部鐩損

患者：【某 50才 含

現病歴：昭和14〜15年頃より左側に悬

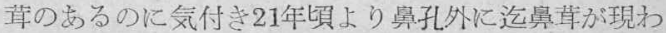
れるようになり，同年 6 月鼻咠甽除を受けたが，11月初 旬に至り再び鼻毒そ生じた。そしてその頃より突然賽 部に朠脹を来し、この電脹は涙管摘出術を受けて治癒 したがそその後22年 1 月頃よりその手術般痕部が再ぴ 腫脤し，受䛦の結果嘘の診断き受け，約20日間ラジウ ム治痖したが，その頃より左眼が充而し，流涙多量視 力障碍老伴うようになり，25年 5 月末来院眼科受猃に より末熟性白内障の䛦断を受けた。然るに26年始め

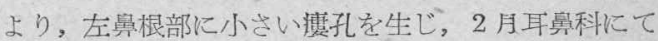
受診ラヂウム治療後の火㑺かと思われたか，その後 次第に掼孔が大となつた為，5月中旬周囲の皮黄を充 分剥離し縫合を埕みたろ゙，結局失敗に終つた。瘦孔い 更に大となり長径 $2 \mathrm{~cm}$ の㨊円形の孔となつた(第6図)。

手術床び過経：本例の様に空隚の上に橋を作るよ な整形には，皮第捧を利用するより他に方法がないと 考觉，27年 5 月 9 日第 1 回手術として左上腕内側に幅

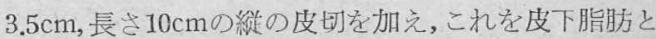

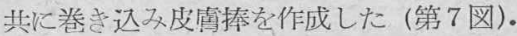

第2 回考手術は患者の鄱合により，6月9日实施し た。すなわち皮䍂捧の上端を切断し欠損部の上部一， ビオゲラチンを淕布して，絹糸をるつて縫合し，2週 間目に縫合部が充分瘾着しその部よりの栄荃を受け 得る事を確めて第3 回目手術を 6 月24日に垁施した (第8図)。すなわら他端を比断し久損部の下部に綘合 した。(第9図)。そして一応は皮䁌捧移殖は成功した が皮膚捧がより突出して甚た゚しく美観を缺を，6月 
第 6 图

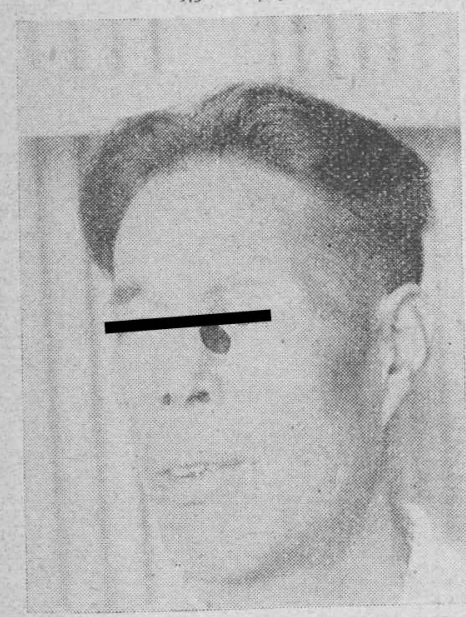

于很前

第 9 网

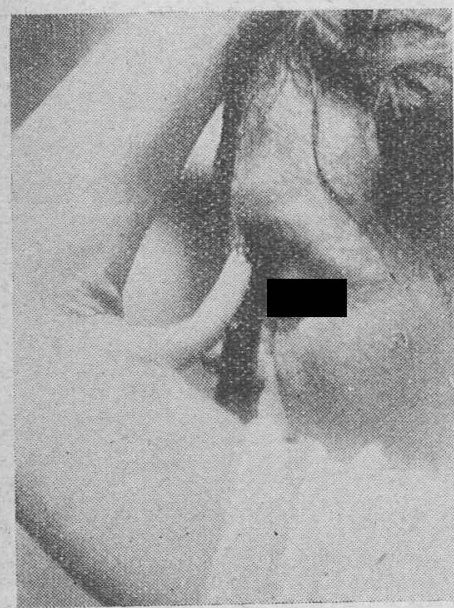

久損部の上部一縫合し， 上腕を頭上涸定
第 7 网

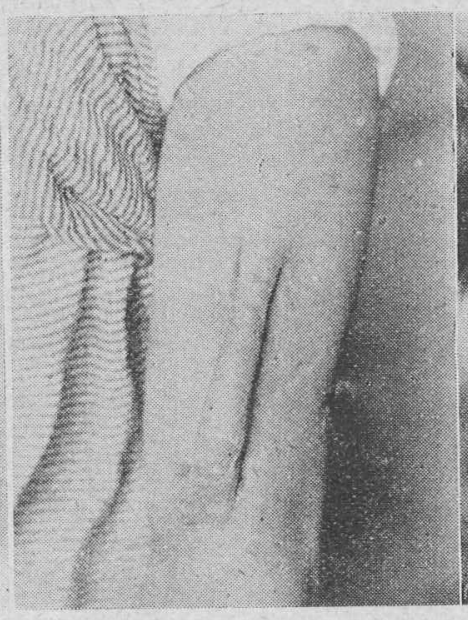

左手内側に作つた蛋高棒

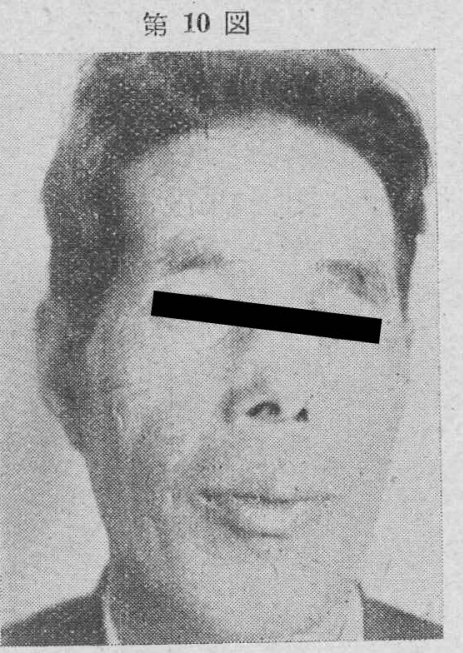

24日手術る行つた。すなわら下端綘 合をはす゚して皮筩棒を孔の中に㨉入 し，孔縁との接触部の皮筫棒に創面

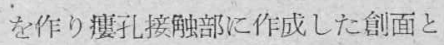
綘合した。度葍棒の尖端は脂肪を一 部除去して，再側を縫合し勩腔に骦 入，棒の先端は悬甲介の代用とし た. 縫合にはずべてカットグートを 用いた(第10図)。

帛の缺損整形には前額部或は煩部等の有荎皮鹰乔を利用する方法があるが，何れも顔面に醜くい 悚痕をのこし，また本症例の如く第１例に於ては両鼻翼・鼻橋・鼻尖を缺損し，また第 2 例のよう に空間の上に橋を渡すが如き整形を要する場合には，何れも皮膚㚏の利用は甚だしく困難で，皮㲊 棒を以てナるのが確笑であると侾える。

その利用する皮膚棒としては，

(1) Leischner は指の末節を利用するう泛を゙述べ，(2) Kausch は足趾を上胶を介して移殖するお 法に成功し，(3 篗木は胸部に皮膚棒を作り遂次上方に移動するす法を行つた。 (4) Joseph は上 腕部に皮膚橑を作り移殖を行い，斎藤は戦時中このう法により多数の経験を得て本法を推賞してい る. 
本症例は何れも(4) の方法によつたものである：第 1 例に矤て, 鼻橋形成に当り二次的に行つた のであるが，これを皮膚棒形成に際し鼻橋部に相当せる部を同時に作成し，一拳に移殖を行つた方 が效果的であつたかと考光る。

鼻橋缺損整形にはLexerの上口唇の有茎粘膜弁を利用する方法もあるがか〉る方法は後に并及び

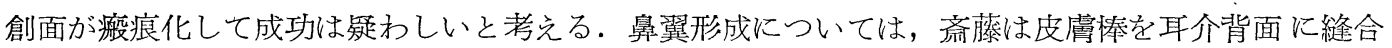
形成する力法を報告しているが，本症例に於ては両悬翼共に缺損しているので之の方法にはよらな かつた。な和皮膚棒形成に当り，斎藤は静脉の縫埋を推賞しているが，第 1 例に之の方法を行つた.

又感染予防のためには，ノボカイン中にペニシリンを混合して用い，な㧺術後創面にも併用注射 した，更に縫合面の癒着を促進せしめるために創面にビオゲラチンを用い綘合面の完全癒合を検す るには皮膚棒の中央部を結禁して血行の有無を見て確かめた。

また上腕の頭上固定には従来ギプス又はシーネを用いた例が多いが，単に繃帯固定のみで充分で めり，然も每日これを巻き変党その都度固定した上腕のマッサージなびに軽い伸展運動を行い，少 しでも㭧者の苦痛軽減するょうに努めた。

\section{結 語}

（1）症例 1 は29才の女子で尋常性狼瘡のため鼻翼・鼻尖・鼻橋の缺損を来し醜形を呈したものに， 皮膚棒の移殖をなしたものである。

(2) 症例 2 は 50 才の男子で, 癌の治療のため ラヂゥム照射を受け，鼻根部に大きな瘦孔を作り ，皮膚棒の移殖をなし，目的を達したものである:

（3）皮膚棒の移殖は，皮膚弁の移植の様に顔面に醜い瘢痕を残寸様な事はなく，かつ確笑に成功 する様に思われる。

撋筹するに当り御指導。御校閲を晹つた恩師中村文雄教授に深謝する；

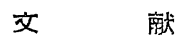
1）日本耳鼻咽喉科全書：第 5 卷
2）斎藤：日耳耳鼻，47；12,1556. 1941
3）高橋・鈴木：実地外科手術犃

4) 笹木・米光: 耳喉科 $12 ; 10,834.1939$
5) Joseph, J : Nasenplastik usw, 2te Abtei1- ung, S, 40?

